Vol. 11 (21), pp. 1924-1934, 26 May, 2016

DOI: 10.5897/AJAR2015.10248

Article Number: AFD5A3458717

ISSN 1991-637X

Copyright (C)2016

Author(s) retain the copyright of this article

http://www.academicjournals.org/AJAR
African Journal of Agricultural

Research

\title{
Effects of water deficit on morphophysiology, productivity and chemical composition of Ocimum africanum Lour (Lamiaceae)
}

\author{
Martielly Santana dos Santos ${ }^{1}$, Lucinéia dos Santos Souza ${ }^{2}$, Carlos Augusto Souza \\ Costa $^{2}$, Fabio Pinto Gomes ${ }^{2}$, Larissa Corrêa do Bomfim Costa ${ }^{2}$, Rosilene Aparecida de \\ Oliveira $^{3}$ and Delmira da Costa Silva ${ }^{2 *}$
}

\footnotetext{
${ }^{1}$ Programa de Pós-graduação em Produção Vegetal, Universidade Estadual de Santa Cruz, Ilhéus, Bahia, Brazil.

${ }^{2}$ Departamento de Ciências Biológica, Universidade Estadual de Santa Cruz, Ilhéus, Bahia, Brazil.

${ }^{3}$ Departamento de Ciências Exatas e Tecnológicas, Universidade Estadual de Santa Cruz, Ilhéus, Bahia, Brazil.
}

Received 5 August, 2015; Accepted 17 February, 2016

\begin{abstract}
Mechanisms by which plants acclimatize to water deficit conditions can affect development and, especially in aromatic plants, the essential oil synthesis. To evaluate the effects of water deficit on Ocimum africanum, seedlings were exposed to water levels corresponding to $100,80,70$ and $60 \%$ of the substrate field capacity. The different watering regimes corresponded to predawn water potentials of $0.5,-0.9,-1.6$ and $-1.9 \mathrm{MPa}$, respectively. Decreased stomatal conductance and increased glandular and tector trichome density were observed under water deficit. In addition, reductions in leaf gas exchange and water consumption under water deficit led to decreased plant height, numbers of leaves and inflorescences, and total biomass production. As a result, lower essential oil yield and water use efficiency for biomass production occurred in the -1.9 MPa treatment. The content and production efficiency of essential oil (quantity of oil produced per unit water consumed) were higher in the -0.9 and $-1.6 \mathrm{MPa}$ treatments. There were no significant differences among treatments in the chemical composition of essential oil, and the major component of essential oil in leaves and inflorescences was isoeugenol in all treatments. The $80 \%$ field capacity watering regime (branch water potential of -0.9 $\mathrm{MPa}$ ) was best for the growth and production of essential oil in 0 . africanum, for the cultivation of aromatic plant under drought economically viable in the semi-arid climatic regions.
\end{abstract}

Key words: Drought adaptation, essential oil, irrigation, water use efficiency.

\section{INTRODUCTION}

The production and composition of secondary metabolites in plants is affected by environmental conditions, physiological characteristics, genetics and evolutionary factors (Selmar and Kleinwächter, 2013).

*Corresponding author. E-mail: delmira@uesc.br. Tel: + 557336805191.

Author(s) agree that this article remain permanently open access under the terms of the Creative Commons Attribution License 4.0 International License 
For essential oil-producing aromatic species, the quantity and chemical composition of secondary metabolites varies according to the cultivation conditions (Marchese et al., 2010; Saeidnejad et al., 2013), among which water availability is a major factor influencing oil yield and quality (Baghalian et al., 2011; Bahreininejad et al., 2013).

Water is a critical factor for the maintenance of primary and secondary metabolism in plants. Drought conditions are normally associated with low precipitation, high evaporative demand, and high temperatures and irradiation, which makes the water deficit a multidimensional stress (Larcher, 2000). Under water deficit conditions, plant growth and development are affected by changes in turgor pressure, cell wall elasticity, carbon assimilation and opening and closing of stomata (Akinci and Lösel, 2012; Wang et al., 2012). In addition, metabolic changes can occur, including increased photorespiration (Lambers et al., 2008), antioxidant enzyme activity (Reddy et al., 2004) and production of secondary metabolites (Saeidnejad et al., 2013; Selmar and Kleinwächter, 2013). In many species, stomatal and biochemical adjustments occur to maintain photosynthesis under moderate water deficits. Partial stomatal closure early after the onset of drought is essential for the control of transpiration rate and may be an important biological strategy for increasing water use efficiency (WUE) by enabling more $\mathrm{CO}_{2}$ to be absorbed per unit of transpired water. Irrigation techniques designed to examine plant responses to water stress and to improve WUE have been developed; these techniques include partial root zone drying and regulated water deficit (Kriedemann and Goodwin, 2003) and cutback (Valipour, 2013). The water deficit approach has been used with aromatic species including Matricaria recutita L. (Baghalian et al., 2011), Thymus daenensis (Bahreininejad et al., 2013), Catharanthus roseus (Jaleel et al., 2008), Ocimum basilicum and Ocimum americanum L. (Khalid, 2006), with the goal of increasing essential oil production.

Species of the genus Ocimum (Lamiaceae) stand out for the quality, quantity and chemical diversity of the essential oils they produce. These oils have been used in applications in the pharmaceutical, cosmetic and food industries (Vani et al., 2009). The main components of essential oils in Ocimum species are estragol, eugenol, methyl eugenol, citral, linalool, geraniol and thymol (Blank et al., 2004; Khalid, 2006; Vani et al., 2009). Some of these compounds have antibacterial (Stefan et al., 2013; Sneha and Sastry, 2011), insecticidal (De Paula et al., 2004) and antioxidant properties (Kaurinovic et al., 2011). According to Blank et al. (2004), the price of Ocimum basilicum essential oil reached US $\$ 110,000 / L$ in the international market because of demand from the fine perfumery industry for its main component, linalool, which is used as a fixative. However, despite the economic importance of Ocimum species, its botanical and agricultural studies are scarce.

An understanding of plant drought tolerance is necessary to determine cultivation conditions that optimize harvest time and essential oil yield and will contribute to improved oil production and quality to meet market standards. This study aimed to investigate the effects of water deficit on gas exchange and biomass partitioning and accumulation. The authors examined plant water use efficiency based on biomass and essential oil production, content, yield and chemical composition in leaves and inflorescences of $O$. africanum under controlled experimental conditions.

\section{MATERIALS AND METHODS}

\section{Plant and growing conditions}

The experiment was conducted in a greenhouse in the Campus of Universidade Estadual de Santa Cruz (UESC), Ilhéus, Bahia, Brazil $\left(14^{\circ} 47^{\prime} 00^{\prime \prime} \mathrm{S}, 3^{\circ} 02^{\prime} 00^{\prime \prime} \mathrm{W}\right)$, from January 07 to April 17, 2012. Voucher materials are deposited at the herbarium of the UESC (number VIC 16.344). Seedlings of Ocimum africanum Lour. were grown from seed and transferred to $10-\mathrm{L}$ pots containing a mixture of soil and sand (3:1) as substrate. After potting, the seedlings were irrigated to field capacity, and the weight of the pots was measured gravimetrically until constant weight was obtained. After acclimatization for 20 days, irrigation was stopped and the pots were covered to control evaporative losses. The evaluations began 5 days after irrigation was stopped. Irrigation was controlled by weighing the pots on alternate days, and the amount of water to be replaced was determined by the difference between the current weight and the corresponding water holding capacity. Four treatments were applied: T1, $100 \%$ of field capacity (the control); T2, $80 \%$; T3, 70\%; and T4, $60 \%$ of field capacity.

During the experiment, photosynthetically active radiation (PAR) in the greenhouse was monitored using S-LIA-M003 light radiation sensors coupled to a Hobo Micro Station data logger (Onset Computer Corp., Bourne, MA). The mean daily PAR measured in the greenhouse was between 8.6 and 23.2 mol photons $\mathrm{m}^{-2} \mathrm{~d}^{-1}$; temperature ranged from 24 to $30.7^{\circ} \mathrm{C}$; and relative humidity $(\mathrm{RH})$ was between 64 and $94 \%$.

\section{Water potential $(\Psi \mathbf{w})$}

Water potential $\left(\psi_{\mathrm{w}}\right)$ was measured in branches at predawn using a pressure chamber 1000 (PMS Instrument Company, Corvallis, OR) according to Scholander et al. (1965). The measurements were performed every 8 days in 60 plants for the entire experimental period.

\section{Leaf gas exchange}

Measurements of leaf gas exchange were performed in mature and completely expanded leaves localized in the third or fourth node from the apex at 20,40, and 60 days from the start of treatment. The evaluations were performed between 08:30 and 12:00 $\mathrm{h}$ in 10 plants per treatment using a portable Li-6400 photosynthesis system (Li-Cor, Lincoln, NB). Net photosynthetic rate $(A)$, stomatal conductance to water vapor $(g s)$, transpiration $(E)$ and the ratio between internal and external $\mathrm{CO}_{2}$ concentrations $(\mathrm{Ci} / \mathrm{Ca})$ were evaluated under an artificial saturating light of $1000 \mu \mathrm{mol}$ photons $\mathrm{m}^{-2} \mathrm{~s}^{-1}$ and an atmospheric $\mathrm{CO}_{2}$ concentration $(\mathrm{Ci} / \mathrm{Ca})$ of $380 \mu \mathrm{mol}$ 
$\mathrm{mol}^{-1}$.

\section{Growth measurements}

The number of leaves and inflorescences per plant was manually counted on day 60. The dry biomass of roots (DBR), stems (DBS), leaves (DBL), inflorescences (DBI) and total biomass (TDB) were obtained by drying at $75^{\circ} \mathrm{C}$ in a circulating air oven until constant biomass was reached. Leaf area (LA) was estimated using an LI3100 Area Meter (Li-Cor), and 30 millimeter ruler was used to determine the height of the plants (HP). The following variables were calculated from the dry biomass and leaf area: specific leaf mass $(\mathrm{SLM})=\mathrm{DBL} / \mathrm{LA}$; relative growth rate $(\mathrm{RGR})=\operatorname{InTDB} 2-$ InTDB1/(T2 - T1); and net assimilation rate (NAR) $=[($ InTDB2 $\operatorname{lnTDB} 1 /(\mathrm{T} 2-\mathrm{T} 1) \times(\operatorname{InLA} 2-\ln L A 1) /(\mathrm{LA} 2-\mathrm{LA} 1)]$, according to Hunt (1990).

\section{Micromorphology}

For scanning electron microscopy (SEM), leaf fragments from each treatment were fixed at room temperature in $2.5 \%$ glutaraldehyde $(\mathrm{v} / \mathrm{v})$ prepared in $0.1 \mathrm{~mol} / \mathrm{L}$ sodium cacodylate buffer $(\mathrm{pH} 6.9)$ for 48 $h$. The fragments were then dehydrated twice in an increasing ethanol series and brought to critical drying point using a CPD-030 (Bal-Tec, Balzers, Liechtenstein) with liquid carbon dioxide. The dried fragments were mounted on aluminum stubs, coated with gold, and examined under a JSM-6390 low-vacuum (LV) SEM (Jeol, Peabody, MA). Determination of stomata and glandular and tector trichome density was performed using electron micrographs of the same magnification.

Water-use efficiency (WUE), production and chemical composition of essential oil

Water use efficiency (WUE) was determined for biomass (total dry weight/water transpired) and essential oil production in leaves and inflorescences (total essential oil produced/water transpired) (g).

\section{Production and chemical composition of essential oil}

Leaves and inflorescences were dried in a circulating air oven at $75^{\circ} \mathrm{C}$ until constant dry biomass was reached. The essential oil was extracted from $100 \mathrm{~g}$ samples of dry biomass through hydrodistillation in $1500 \mathrm{~mL}$ distilled water for 90 min using a Clevenger apparatus; the extractions were performed in quadruplicate. The essential oil content was determined based on the volume extracted per $100 \mathrm{~g}$ dry biomass (\% w/v); essential oil yield was determined by multiplying the content by the average value of leaf or inflorescence dry biomass $\left(\mathrm{g} \mathrm{plant}^{-1}\right)$.

The essential oil was analyzed by gas chromatography using a Varian Saturn 3800 (Varian, Palo Alto, CA) equipped with a flame ionization detector (GC-FID) and VF-5ms capillary column $(30 \mathrm{~mm}$ $\times 0.25 \mathrm{~mm} \times 0.25 \mu \mathrm{m}$ film thickness), using helium as the carrier gas at a flow rate of $1.2 \mathrm{~mL} \mathrm{~min}{ }^{-1}$. The injector and detector temperatures were 250 and $280^{\circ} \mathrm{C}$, respectively. The column temperature program began at $70^{\circ} \mathrm{C}$, increased by $8^{\circ} \mathrm{C} \min ^{-1}$ to $200^{\circ} \mathrm{C}$ and by $10^{\circ} \mathrm{C} \mathrm{min}^{-1}$ to $260^{\circ} \mathrm{C}$, and was held at $260^{\circ} \mathrm{C}$ for 5 min. One milliliter of a $10 \%$ solution of oil in chloroform was injected in the 1:10 split mode. The concentration of volatile constituents was calculated based on the full area of each peak in relation to the total area of all constituent peaks. Qualitative analysis of the essential oil was carried out using a Chromopack 2000 MS/MS mass spectrometer (Varian) with the same VF-5ms column and temperature program. The transfer line temperature was $250^{\circ} \mathrm{C}$ and the trap temperature was $220^{\circ} \mathrm{C}$. The chemical constituents were identified by computer comparison with the apparatus library and literature, and linear retention indices were calculated by injecting a series of $n$-alkanes $\left(\mathrm{C}_{8}-\mathrm{C}_{26}\right)$ under the same chromatographic conditions as used for the samples (Adams, 1995).

\section{Experimental design}

The experiment was conducted following a completely randomized design, in a split-plot array with four water conditions: $100 \%(\mathrm{~T} 1)$, $80 \%$ (T2), $70 \%$ (T3) and 60\% (T4) of field capacity; four evaluation times $(0,20,40$ and 60 days); and 10 replications per treatment, (n $=160$ plants). The data were examined by analysis of variance (ANOVA, F-test). For the treatment averages, polynomial regression models were adjusted using Sisvar 5.3 (Ferreira and Sisvar, 2010). Tukey tests were used to assess the average values within treatments for each evaluation time. Significance was defined as $P \leq 0.05$.

\section{RESULTS}

\section{Water relations and leaf gas exchange}

Water deficit treatments in 0 . africanum resulted in a significant decrease $(P \leq 0.001)$ in predawn branch water potential $\left(\Psi_{\mathrm{w}}\right)$ throughout the experimental period. Values ranging from -0.3 to $-0.5 \mathrm{MPa}$ and from -0.4 to 2.2 $\mathrm{MPa}$ were measured in the well watered and water deficit (more severe) treatments, respectively (Figure 1 ).

A significant $(P<0.01)$ interaction was observed between water deficit treatment and time of evaluation for leaf gas exchange variables: $A$, gs and $E$ decreased linearly with increasing treatment time. Photosynthetic parameters decreased with increasing duration of drought stress (Figure $2 \mathrm{~A}-\mathrm{C}$ ). $A$ and gs were positively correlated in all treatments $\left(R^{2} \geq 0.92\right)$ (Figure 2D); the reduced transpiration rate indicated that stomatal limitation was an efficient mechanism for reducing water loss (Figure 2C).

\section{Morphological aspects of biomass partitioning}

$O$. africanum plants cultivated under the highest water deficit conditions showed reduced growth. Dry biomass of all plant parts (roots, stems, leaves and inflorescences) decreased linearly with increasing water deficit (Table 1). At $\Psi_{\mathrm{w}}$ of $-1.9 \mathrm{MPa}$ (severe deficit), biomass was reduced most in stems and inflorescences, with values that were 60 and $69 \%$ lower, respectively, than those of the control treatment $\left(\Psi_{\mathrm{w}} \sim 0.5 \mathrm{MPa}\right)$ (Table 1). The allometric relationship observed in the ratio of roots to aerial parts (R/AP) showed a quadratic response with a maximum value of $0.106 \mathrm{~g}$ at $\Psi_{\mathrm{w}}=-1.04 \mathrm{MPa}$.

Plant height, leaf area, number of leaves and inflorescences, relative growth rate and net assimilation rate decreased linearly, with the lowest values in the plants subjected to the highest water stress (Table 1). 


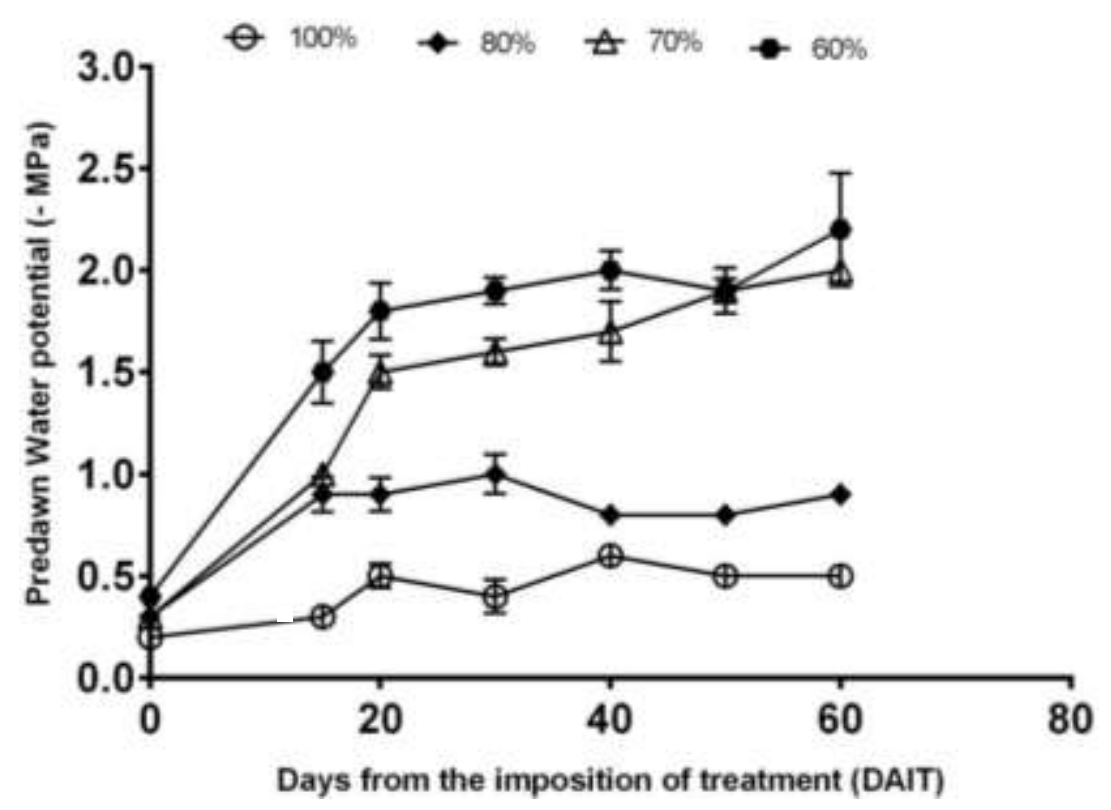

Figure 1. Predawn water potential $\left(\Psi_{\mathrm{w}}\right)$ measured in branches of $O$. africanum under different watering regimes. Points are means $(n=5)$ and bars represent standard error.
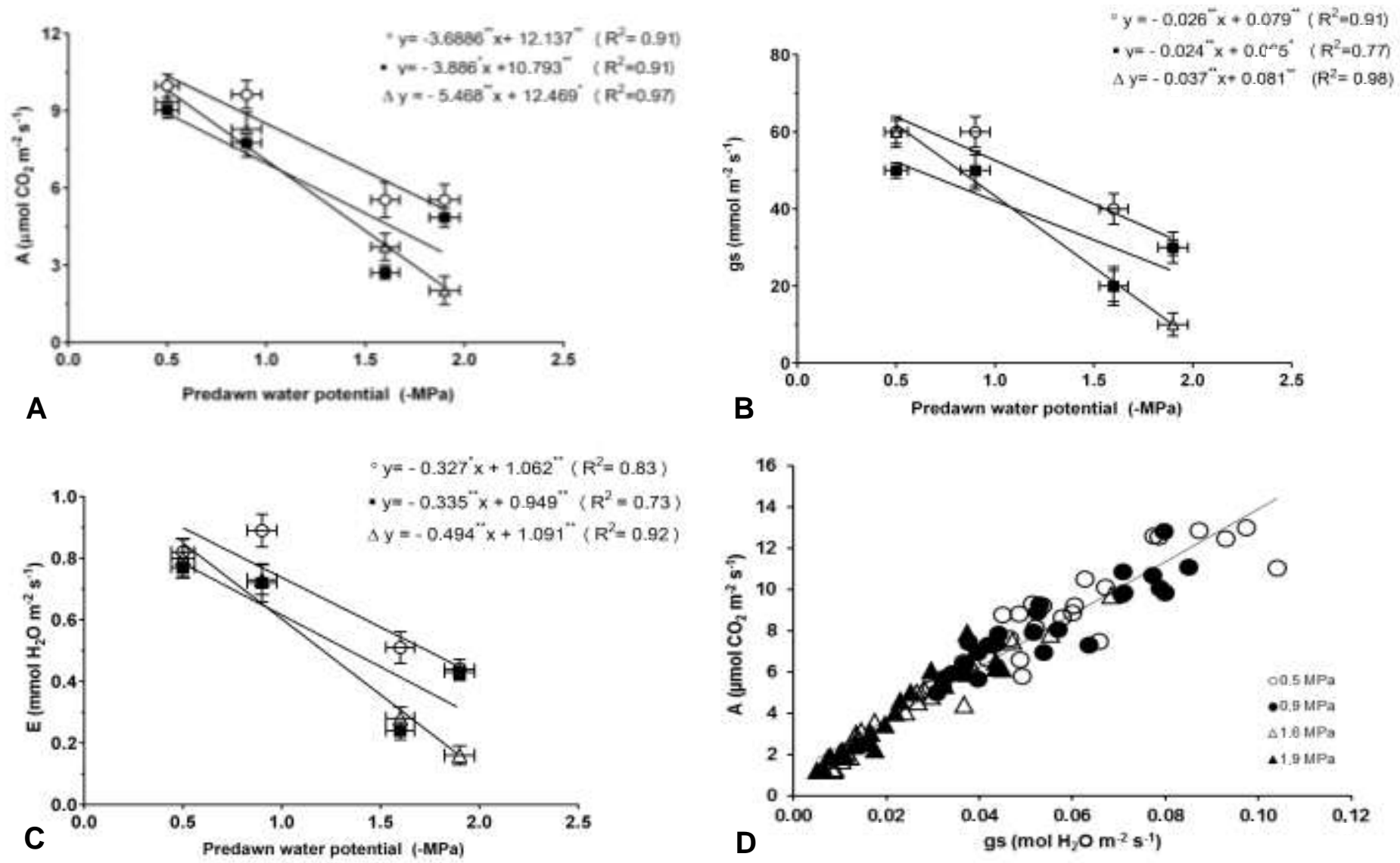

Figure 2. Net photosynthetic rate, $A(\mathrm{~A})$; stomatal conductance, gs $(\mathrm{B})$; transpiration rate, $E(\mathrm{C})$; and relationship between $g s$ and $A$ in leaves of $O$. africanum subjected to soil water deficit as indicated by the predawn water potential measured in branches ( $\square$ w) (D). Points are means $(n=5)$; bars represent standard error. 
Table 1. Plant growth variables in $O$. africanum after 60 days of water deficit treatments at different branch water potentials. Values are means ( \pm s.e.) of five replicates.

\begin{tabular}{|c|c|c|c|c|c|c|}
\hline \multirow{2}{*}{ Variable } & \multicolumn{4}{|c|}{ Predawn water potential (-MPa) } & \multirow{2}{*}{ Equation } & \multirow{2}{*}{$R^{2}$} \\
\hline & $0.5 \mathrm{MPa}$ & $0.9 \mathrm{MPa}$ & $1.6 \mathrm{MPa}$ & $1.9 \mathrm{MPa}$ & & \\
\hline RDB & $3.1 \pm 0.5$ & $1.9 \pm 0.1$ & $1.5 \pm 0.2$ & $1.2 \pm 0.1$ & $\hat{y}=-1.278^{\star *} x+3.513^{* *}$ & 0.90 \\
\hline SDB & $11.7 \pm 0.2$ & $7.9 \pm 0.9$ & $5.3 \pm 0.2$ & $4.7 \pm 0.3$ & $\hat{y}=-4.864^{* *} x+13.423^{* *}$ & 0.92 \\
\hline LDB & $6.3 \pm 0.6$ & $4.8 \pm 0.5$ & $3.7 \pm 0$ & $3.5 \pm 0.3$ & $\hat{y}=-1.988^{\star *} x+7.003^{* *}$ & 0.93 \\
\hline IDB & $15.7 \pm 0.6$ & $9.5 \pm 0.9$ & $5.3 \pm 0.5$ & $4.8 \pm 0.5$ & $\hat{y}=-7.522^{* *} x+18.001^{* *}$ & 0.91 \\
\hline TDB & $36.9 \pm 0.9$ & $24.2 \pm 2.3$ & $15.7 \pm 0.5$ & $14.2 \pm 1.0$ & $\hat{y}=-15.652^{* *} x+41.941^{* *}$ & 0.92 \\
\hline $\mathrm{R}: \mathrm{PA}$ & $0.09 \pm 0.02$ & $0.1 \pm 0.02$ & $0.1 \pm 0.01$ & $0.09 \pm 0.01$ & $\hat{y}=-0.069 \times 2^{*}+0.142 x^{* *}+0.032^{*}$ & 0.63 \\
\hline HEI & $63.2 \pm 2.7$ & $59.2 \pm 1.1$ & $52.6 \pm 0.7$ & $53.2 \pm 0.9$ & $\hat{y}=-7.678^{\star \star} x+66.412^{\star \star}$ & 0.94 \\
\hline SLM & $42.8 \pm 1.9$ & $45.0 \pm 2.0$ & $50.1 \pm 3.3$ & $55.2 \pm 3.3$ & $\hat{y}=8.478^{\star *} x+37.909^{\star *}$ & 0.95 \\
\hline $\mathrm{NI}$ & $129.4 \pm 6.8$ & $88.0 \pm 9.1$ & $62.2 \pm 5.8$ & $53.6 \pm 6.8$ & $\hat{y}=-51.251^{* *} x+146.08^{\star *}$ & 0.93 \\
\hline NL & $1149 \pm 96$ & $853 \pm 80$ & $620 \pm 30$ & $558 \pm 50$ & $\hat{y}=-407.87^{* *} x+1294.4^{* *}$ & 0.94 \\
\hline LA & $1478 \pm 110$ & $1066 \pm 90.3$ & $734 \pm 23.3$ & $644 \pm 86$ & $\hat{y}=-576.63^{\star *} x+1686.6^{\star *}$ & 0.95 \\
\hline RGR & $33.7 \pm 0.3$ & $29.1 \pm 1.1$ & $24.7 \pm 0.3$ & $23.5 \pm 0.8$ & $\hat{y}=-7.125^{\star \star} x+36.488^{\star}$ & 0.97 \\
\hline NAR & $0.6 \pm 0.02$ & $0.5 \pm 0.02$ & $0.4 \pm 0.01$ & $0.4 \pm 0.01$ & $\hat{y}=-0.165^{* *} x+0.659^{* *}$ & 0.90 \\
\hline
\end{tabular}

RDB (root dry biomass, g); SDB (stem dry biomass, g); LDB (leaf dry biomass, g); IDB (inflorescence dry biomass, g); TDB (total dry biomass, g); HEI (height, $\mathrm{cm}$ ); SLB (specific leaf biomass, $\mathrm{g} \mathrm{m}^{-2}$ ); $\mathrm{NI}$ (number of inflorescences); NL (number of leaves); LA (leaf area, $\mathrm{cm}^{2}$ ); RGR (relative growth rate, $\mathrm{mg} \mathrm{g}^{-1} \mathrm{~d}^{-1}$ ); NAR (net assimilation rate, $\mathrm{mg} \mathrm{cm}^{-2} \mathrm{~d}^{-1}$ ).

The most evident morphological differences between treatments were reduced height $(16 \%)$, number of leaves $(51 \%)$ and inflorescences $(59 \%)$ at low $\Psi_{\mathrm{w}}(-1.9 \mathrm{MPa})$ as compared to $\Psi_{\mathrm{w}}=-0.5 \mathrm{MPa}$ (Table 1). However, drought stress corresponded to a significant $(29 \%)$ increase in specific leaf mass at $\Psi_{\mathrm{w}}=-1.9 \mathrm{MPa}$, which was related to the $56 \%$ reduction in foliage in this treatment.

\section{Leaf micromorphology}

$O$ africanum had stomata and glandular and tector trichomes on both epidermal faces. The trichomes were classified as peltate glandular, with four secretory cells in the head and protected by a cuticle; multicellular tector trichomes had cuticular ornaments (Figure $3 \mathrm{~A}-\mathrm{C}$ ).

The density of capitate, peltate glandular and tector trichomes was influenced by water deficit. The density of glandular trichomes adjusted linearly on the adaxial surface of the epidermis; these trichomes showed a 9$\mathrm{mm}^{2}$ quadratic adjustment on the abaxial surface, with maximum mean values of 10 trichomes $\mathrm{mm}^{-2}$ for $\psi_{\mathrm{w}}$ of $1.5 \mathrm{MPa}$. At $\Psi_{\mathrm{w}}=-1.9 \mathrm{MPa}$, tector trichomes showed a quadratic adjustment with maximum mean value of 23 trichomes $\mathrm{mm}^{-2}$ for the abaxial surface, and a linear adjustment for the abaxial face with 31 trichomes $\mathrm{mm}^{-2}$ (Figure 4A and B).

Stomatal density showed quadratic adjustments with significant increases $(P<0.01)$ in the number of stomata in the adaxial and abaxial surfaces at $\Psi_{\mathrm{w}}=-1.6$ and -1.9 $\mathrm{MPa}$. The maximum stomatal density occurred at $\Psi_{\mathrm{W}}=-$ 1.6 $\mathrm{MPa}$, with 10 and 12 stomata $\mathrm{mm}^{-2}$ in the adaxial and abaxial surfaces, respectively (Figure 4C).

\section{Essential oil production and water use efficiency}

The essential oil content in leaves and inflorescences was significantly affected by water deficit and was highest at the lowest water potentials in branches (Figure 5A). The essential oil yield of leaves and inflorescences decreased significantly with increasing severity of the water deficit $\left(R^{2}=0.95\right)$ (Figure $\left.5 \mathrm{~B}\right)$.

The WUE based on the productivity of total biomass (WUE $\mathrm{bm}$ ) and essential oil (WUE oil) showed quadratic responses, reaching a maximum of $5.54 \mathrm{~g} / \mathrm{L}$ at $\psi_{\mathrm{w}}=-1.1$ $\mathrm{MPa}$. In leaves and inflorescences, the maximum WUE was 0.75 and $2.7 \mathrm{~g} / \mathrm{L}$ at $\Psi_{\mathrm{w}}=-1.24$ and $-1.15 \mathrm{MPa}$, respectively (Figure 6 ).

Water deficit had little effect on the chemical composition of the essential oil extracted from leaves and inflorescences of $O$. africanum (Tables 2 and 3). Nine chemical compounds were identified in the essential oil; the major component was isoeugenol. There were difference in the composition of the essential oil between leaves and inflorescences: linalool was present only in the leaves; and $\gamma$-curcumen, caryophyllene oxide, fenchol and (endo)-fenchol only occurred in the inflorescences (Tables 2 and 3). Changes in the content, yield and WUE of essential oil production after 60 days of the treatments caused only small variations in the chemical composition of the oil (Tables 2 and 3 ). In leaves, the concentration of isoeugenol remained stable at the different water potentials, whereas in inflorescences, the relative 


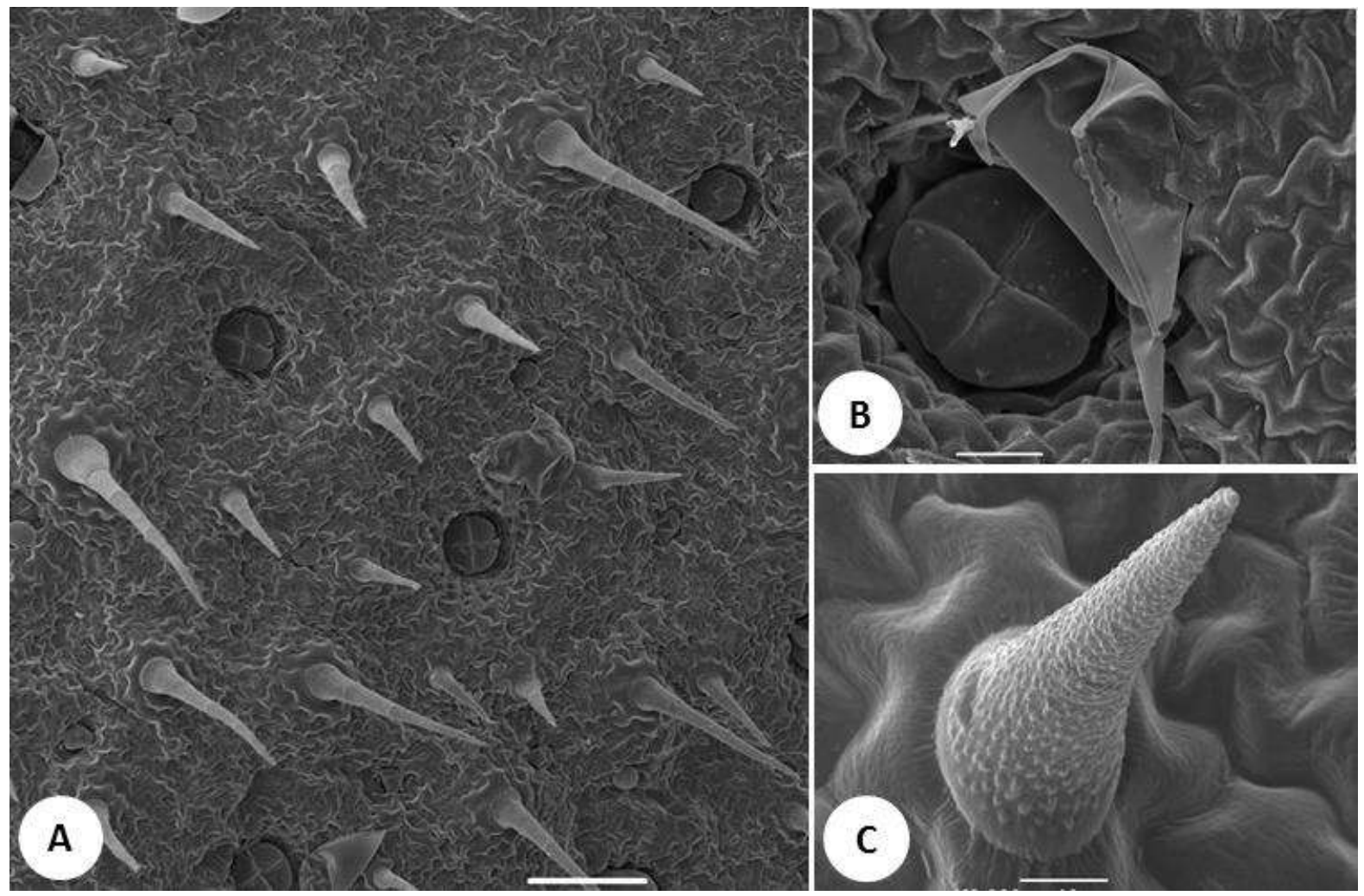

Figure 3. Scanning electron micrograph of leaf surface of $O$. africanum; (A) Overview of epidermis, abaxial surface; (B) Tector trichome; (C) Peltate glandular trichome. Scale bars $=100 \mu \mathrm{m}$ (A and C), $20 \mu \mathrm{m}(\mathrm{B})$.

concentration of isoeugenol varied among the treatments (Table 3).

\section{DISCUSSION}

Plants subjected to water deficit have mechanisms for acclimating to these environmental conditions, including high level of expression of many genes and transcription factors (Rehem et al., 2012; Osakabe et al., 2014), increase in absicisc acid biosynthesis, stomatal closure and intracellular somatically active solutes accumulation (Lisar et al., 2012; Osakabe et al., 2014). These biochemical and physiological adjustment helps maintain cellular turgor and metabolic homeostasis and can be indicator of capacity of plant respond to drought stress (Akinci and Losel, 2012). All changes can interfere with growth patterns and, in aromatic plants, with essential oil biosynthesis.

Water deficit caused reductions in net photosynthetic rate and stomatal conductance in $O$. africanum. This response pattern was attributed to partial stomatal closure, which affects photosynthesis (Akinci and Lösel, 2012; Lisar et al., 2012), showing that stomata in this species are strongly sensitive to drought. The decreases in stomatal conductance were accompanied by a drop in water potential throughout the experimental period. The reduced conductance is thus related to a decrease in water lost to transpiration (Guha et al., 2010) and an increase in water use efficiency, which is an important protection mechanism against leaf dehydration and loss of enzyme activity, both of which affect carbon fixation (Parry et al., 2002; Saeidnejad et al., 2013).

Reduced growth in response to drought is common in plants and is one of the first responses to water limitation. Growth is affected by drought through decreased cell turgor pressure, which leads to inhibition of cell expansion (Cominelli et al., 2008; Harb et al., 2010). In the aromatic plants, Matricaria recutita L. (Baghalian et al., 2011), Thymus daenensis subsp daenensis (Bahreininejad et al., 2013), Artemisia annua L. (Marchese et al., 2010) and Salvia officinalis L. (Bettaieb et al., 2009), growth changes under water deficit included reductions in leaf area, pigment contents, and leaf, flower and stem biomass. In $O$. africanum, the reduction in biomass production under the most severe water deficit conditions was mainly related to the decreased stomatal conductance and photosynthetic rate. Water availability is essential for cell expansion and division, which are also important during the flowering stage. Water deficit reduced flower size and nectar volume in Epilobium angustifolium, although nectar concentration was 

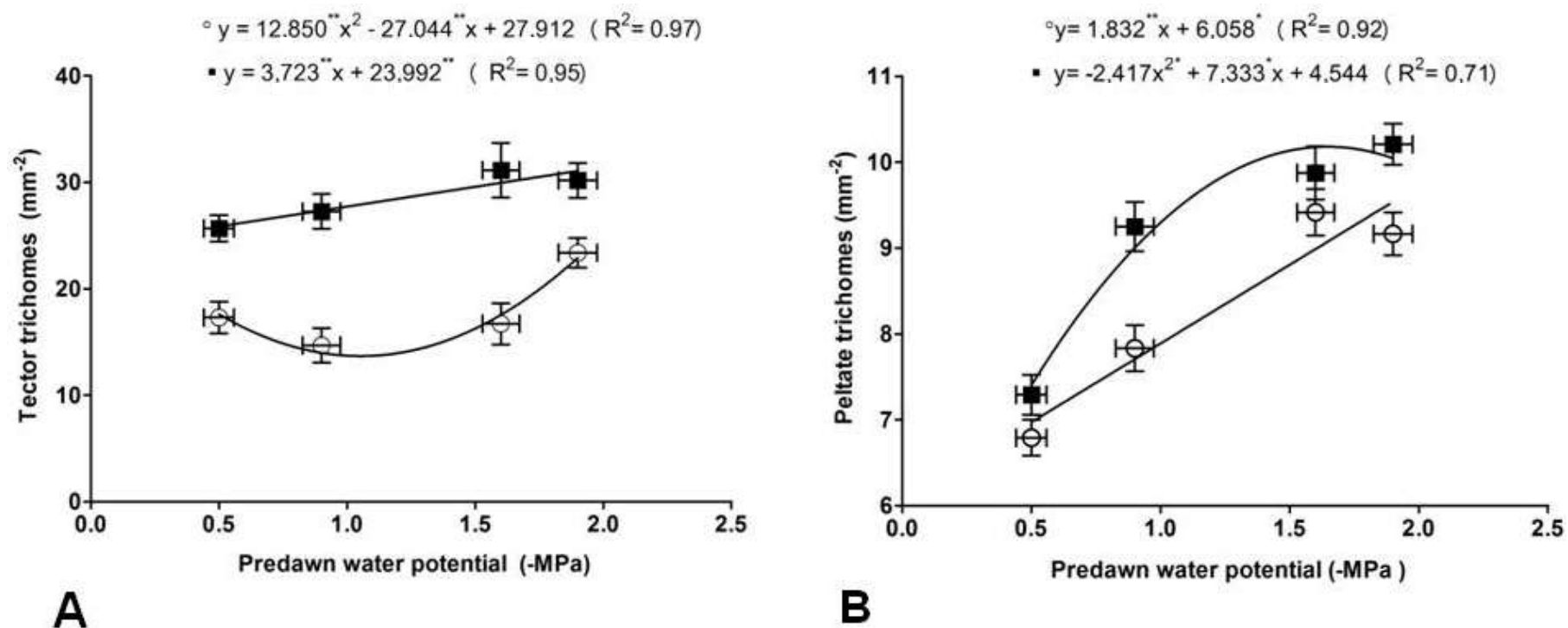

A

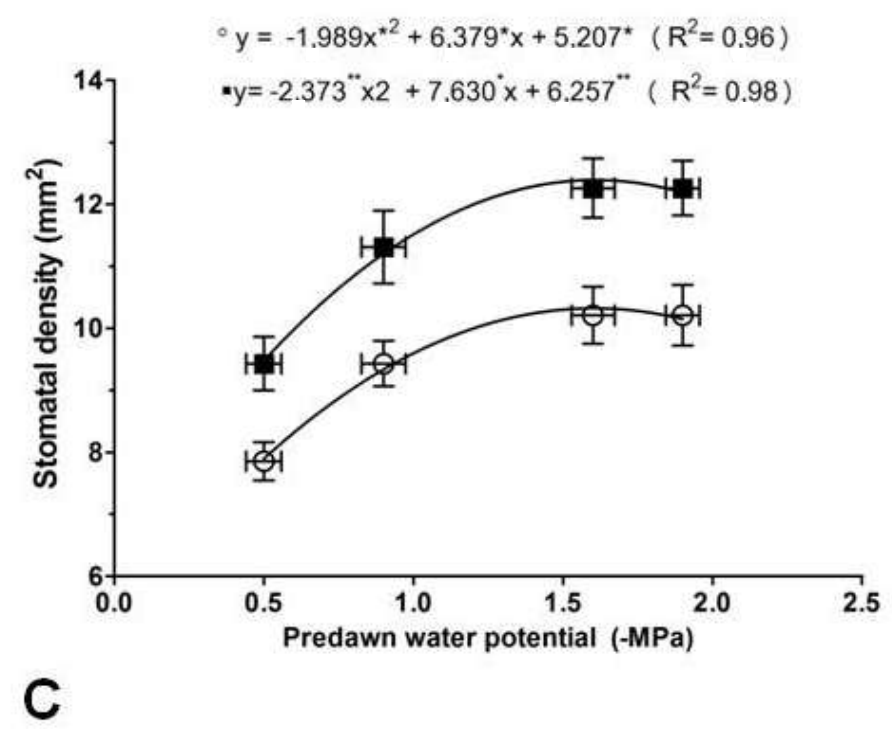

Figure 4. Density of peltate glandular trichomes (A) and tector trichomes (B); and stomatal density on the adaxial (circles) and abaxial (squares) surfaces of Ocimum africanum at different water potentials (C). Values are means of five replicates; bars indicate standard error.

unchanged (Carroll et al., 2001).

The reduction in relative growth rate of $O$. africanum at lower water potential $\left(\Psi_{\mathrm{w}}=-1.6\right.$ and $\left.-1.9 \mathrm{MPa}\right)$ suggested physiological changes, which were reflected in the reduced net assimilation rate. Relative growth rate is indicative of adaptations of plants to environmental conditions and is determined by changes in biomass (Hunt, 1990). The reduction in leaf number and area in $O$. africanum with increased water deficit (Table 1) showed strong plasticity to adapt to water availability. A decrease in photosynthetic area is an important mechanism under drought conditions, resulting in less light absorption and water loss by transpiration, and thus in higher water use efficiency (Bahreininejad et al., 2013; Shao et al., 2008).

The allometric relationship observed in the increased ratio of roots to aerial parts in $O$. africanum reflected a complex system that involves nutrient uptake and vegetative growth to maximize water absorption and assimilate flow in roots, consistent with the functional balance theory (Poorter et al., 2012).

The increased density of stomata and glandular and tector trichomes in $O$. africanum was associated with decreased leaf area in treatments with lower water potential. The presence of tector trichomes on leaf surfaces may contribute to the formation of a humid microclimate that reduces transpiration and heating by helping to reflect solar radiation (Guerfel et al., 2009). This an important morphological characteristic for tolerance to water stress in leaves of amphistomatic species such as $O$. africanum. 

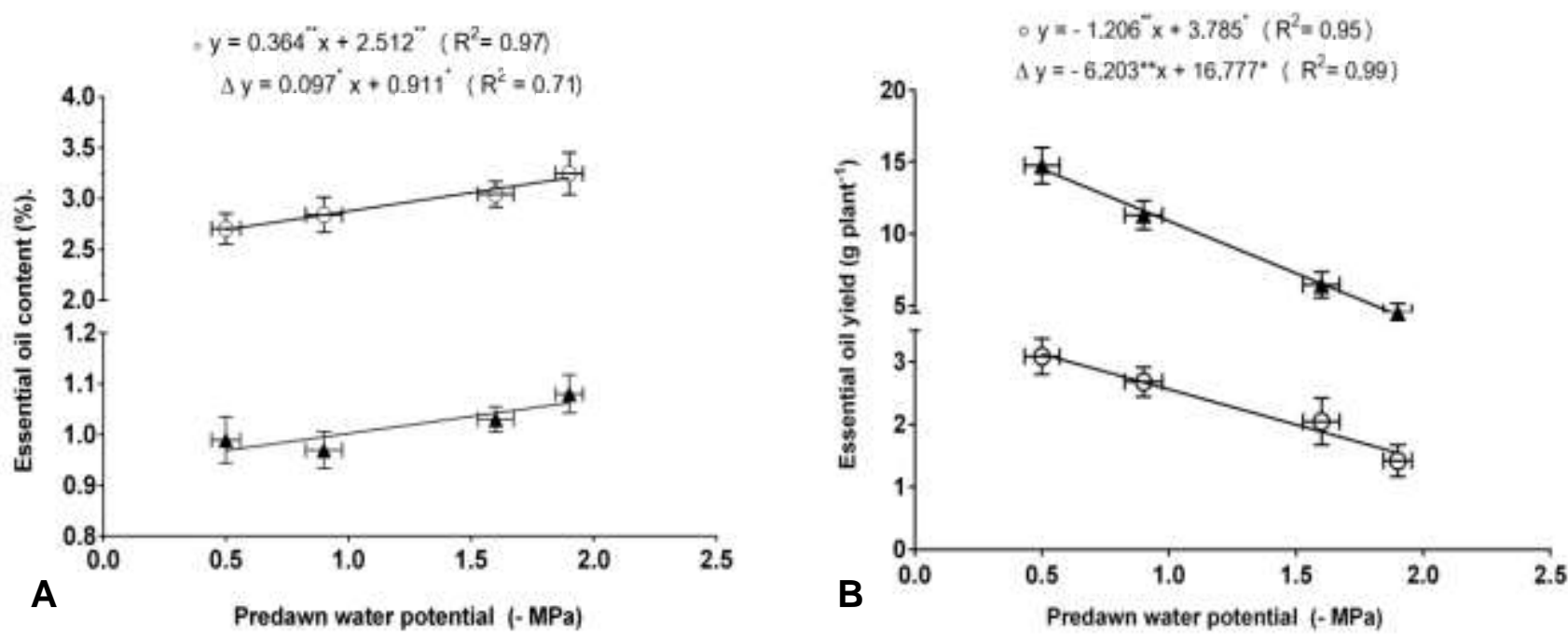

Figure 5. Essential oil contents in leaves $(\circ)$ and inflorescences $(\Delta)(A)$; Essential oil yield in leaves $(\circ)$ and inflorescences $(\Delta)$ of Ocimum africanum 60 days after water deficit was imposed (B). Values are means of five replicates; bars indicate standard error.

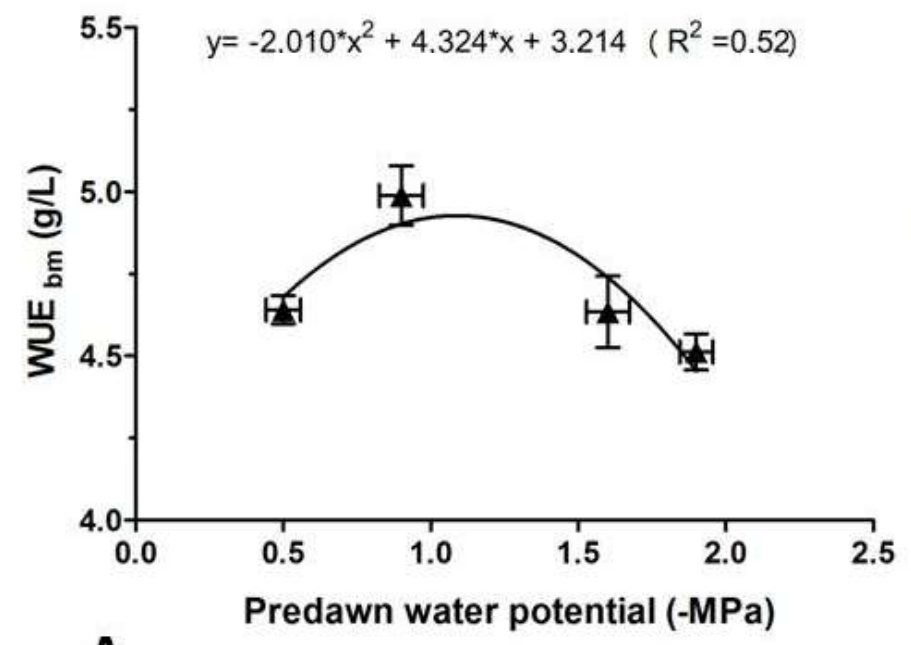

A
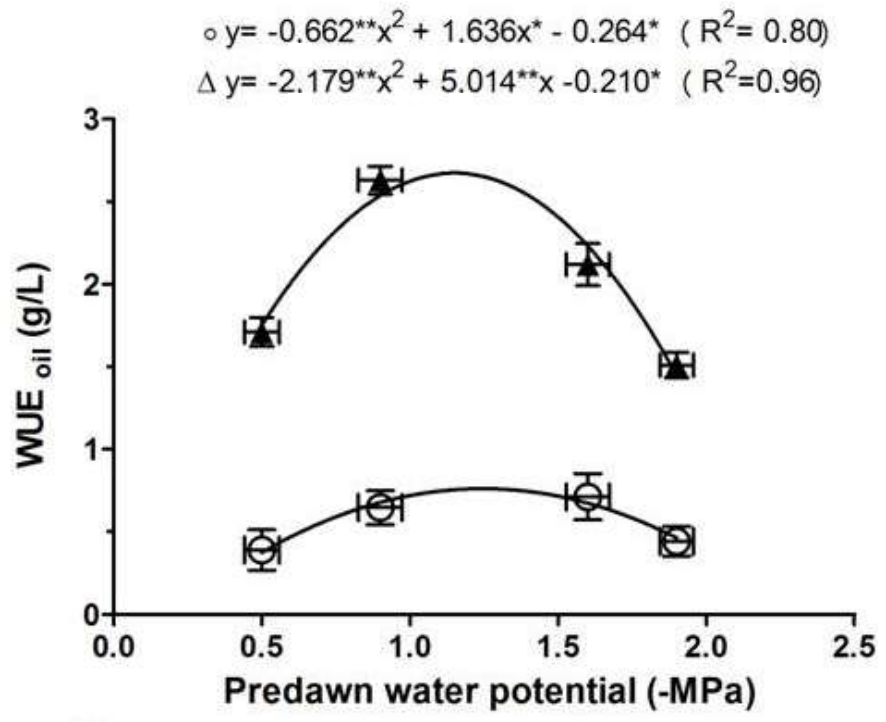

B

Figure 6. Water use efficiency of biomass production (A) and of essential oil production (B) by $O$. africanum leaves $(O)$ and inflorescences $(\Delta), 60$ days after the start of the treatments. Values are means of five replicates; bars indicate standard error.

In some species in the Lamiacea family, synthesis and storage of essential oils occur in secretory structures in leaves and inflorescences (Bahreininejad et al., 2013; Bettaieb et al., 2009; Khalid, 2006; Singh-Sangwan et al., 1994). The effects of water deficit on biomass production and glandular trichome density may influence the content, yield (Baghalian et al., 2011) and chemical composition of essential oils (Saeidnejad et al., 2013). In qualitative and quantitative aspects, the essential oils are chemically unstable and may undergo changes depending on the severity of stress (Sangwan et al., 2001). O. africanum under water deficit increased the glandular trichomes density and essential oil content. There were no significant changes in the relative percentage of the main constituents of the essential oil from the leaves and inflorescence.

An effect of drought on water use efficiency per liter of essential oil produced in aerial parts was observed in Thymus daenensis (Bahreiniejad et al., 2013), and here, flowers of $O$. africanum had higher essential oil yield and 
Table 2. Relative percentages of components in essential oil extracted from leaves of Ocimum africanum under water deficit treatments. KI: (Kovats indices).

\begin{tabular}{|c|c|c|c|c|c|c|}
\hline \multirow{3}{*}{ Compound } & \multirow{3}{*}{ KI literature } & \multirow{3}{*}{$\mathrm{KI}$ experiment } & \multicolumn{4}{|c|}{ Predawn water potential (-MPa) } \\
\hline & & & 0.5 & 0.9 & 1.6 & 1.9 \\
\hline & & & \multicolumn{4}{|c|}{ Relative percentage } \\
\hline Linalool & 1098 & 1095 & 0.76 & 0.28 & 0.70 & 0.38 \\
\hline Methyl(Z)-cinnamate & 1301 & 1302 & 4.95 & 4.51 & 5.09 & 5.19 \\
\hline (Z)-isoeugenol & 1402 & 1396 & 92.00 & 94.24 & 92.89 & 93.54 \\
\hline (E)-caryophyllene & 1418 & 1425 & 0.63 & 0.49 & 0.71 & 0.47 \\
\hline Cis-thujopsene & 1429 & 1433 & 0.54 & 0.43 & $0 \quad 0.62$ & 0.43 \\
\hline Oxygenated monoterpenes & & & 5.71 & 4.79 & 5.79 & 5.57 \\
\hline Phenylpropanoids & & & 92.00 & 94.24 & 92.89 & 93.54 \\
\hline Sesquiterpenes & & & 1.17 & 0.92 & 1.33 & 0.90 \\
\hline Total identified (\%) & & & 99.88 & 99.94 & 100 & 100 \\
\hline
\end{tabular}

Table 3. Relative percentages of components in essential oil extracted from inflorescences of Ocimum africanum under water deficit treatments.

\begin{tabular}{lcccccc}
\hline & & & \multicolumn{4}{c}{ Predawn water potential (-MPa) } \\
\cline { 4 - 7 } Component & KI literature & KI experiment & $\mathbf{0 . 5}$ & $\mathbf{0 . 9}$ & $\mathbf{1 . 6}$ & $\mathbf{1 . 9}$ \\
\cline { 4 - 7 } & & 1096 & 0.91 & 0.84 & 0.58 & 0.58 \\
\hline Fenchol & 1087 & 1218 & 0.11 & 0.20 & - & - \\
(Endo)-fenchyl acetate & 1220 & 1302 & 2.25 & 2.41 & 1.56 & 2.36 \\
(Z)-methyl cinnamate & 1301 & 1400 & 89.27 & 88.70 & 92.59 & 90.50 \\
(Z) isoeugenol & 1402 & 1427 & 2.92 & 3.09 & 1.97 & 2.26 \\
(E)-caryophyllene & 1418 & 1434 & 230 & 2.73 & 1.76 & 2.18 \\
Cis-thujopsene & 1429 & 1484 & 1.56 & - & 1.54 & 1.32 \\
$\gamma$-Curcumene & 1480 & 1580 & 0.31 & 0.21 & - & 0.53 \\
Caryophyllene oxide & 1581 & & 3.27 & 3.45 & 2.14 & 2.93 \\
Oxygenated monoterpenes & & & 89.27 & 88.70 & 92.59 & 90.50 \\
Phenylpropanoids & & & 6.77 & 5.83 & 5,27 & 5.77 \\
Sesquiterpenes & & & 0.31 & 0.21 & - & 0.53 \\
Oxygenated Sesquiterpenes & & & 99.62 & 98.19 & 100 & 99.2 \\
Total identified (\%) & & & & & &
\end{tabular}

$\mathrm{KI}$ : Kovats indices.

WUE at the lowest water potential.

These results suggest that the plants invested proportionally more photoassimilate in the production of essential oil per water unit consumed at $\Psi_{\mathrm{w}}$ of $-0.9 \mathrm{MPa}$, primarily in flowers. Understanding the effects of drought on essential oil production in these organs will help to maximize the raw material obtained before and during harvest. In $O$. africanum, essential oil content was higher in leaves than in inflorescences, and the largest density of glandular trichomes was found in the leaves. In addition, the highest essential oil content occurred under the most severe water deficit conditions. Simon et al. (1992) observed an increase in essential oil content in $O$. basilicum from mild $(-0.68 \mathrm{MPa})$ to moderate $(-1.12$ $\mathrm{MPa}$ ) water deficit, from 3.1 to $6.2 \mu \mathrm{L} \mathrm{g}^{-1}$.
Increased essential oil content under water stress has been attributed to the production of high concentrations of terpenes, isoprenoids and phenylpropanoids by plants (Delfine et al., 2005). In O. africanum, the essential oil yield of leaves and inflorescences was inversely proportional to the essential oil contents in those organs. Thus, this study verified that water deficiency promoted increased essential oil content but decreased essential oil yield in this species. This finding is attributed to reduced numbers of leaves and inflorescences under water deficit, which led to lower biomass.

Understanding the relationship between water use and essential oil production and quality is fundamental in order for the cultivation of aromatic plants under drought to be economically viable. Furthermore, the presence of 
essential oil in leaves and inflorescences, and differential responses of essential oil content and yield as observed in this study, may reduce the cost of processing by the harvest of the organs and drying period. Here, for $O$. africanum, increased essential oil content and water use efficiency in the production of essential oil were demonstrated for both organs under moderate water deficit. Methyl (Z)-cinnamaldehyde, caryophyllene and tujupesno were observed in the essential oil of leaves and inflorescences. However, isoeugenol was the major component in both organs, while derivatives of fenchol were observed in the oil of inflorescences. Isoeugenol is a chemical isomer of eugenol, which is known for its antifungal, antibacterial and antioxidant properties (Dubey et al., 2000; Lemos et al., 2005; Pereira and Maia, 2007), and which is broadly used in the perfume, cosmetic and pharmaceutical industries (Oliveira et al., 2008; Costa et al., 2010). Furthermore, eugenol and isoeugenol obtained from essential oils are viable economical sources for the production of valine by bioconversion (Daugsch and Pastore, 2005; Zhao et al., 2006; Ashengroph et al., 2012). Thus, considering the elevated concentration of isoeugenol in leaves and inflorescences even under water deficit, $O$. africanum may hold potential as a source of eugenol and vanillin for industry. In addition, the cost of managing the harvest and post-harvest may be reduced because leaves and inflorescences do not need to be processed.

\section{Conclusion}

The results presented here showed that irrigation at $80 \%$ of the field capacity (water potential of $-0.9 \mathrm{MPa}$ ) provides the best condition for the growth and production of essential oil in $O$. africanum. Under these conditions, the yield and quality of essential oil make cultivation of $O$. africanum economically viable. No change were observed in the chemical composition of the essential oil in leaves and inflorescences, and the essential oil content and the quantity of oil produced per unit water consumed increased under moderate water deficit. More detailed studies are necessary to support the development of appropriate field management conditions to achieve maximum essential oil yield while conserving water resources.

\section{Conflict of Interests}

The authors have not declared any conflict of interests.

\section{ACKNOWLEDGEMENTS}

The authors thank the Brazilian Higher Education Council (CAPES) and the Brazilian National Council for Scientific and Technological Development (CNPq) for financial support and fellowships provided.

\section{REFERENCES}

Adams RP (1995). Identification of essential oil components by gas chromatography/ mass spectroscopy. Illinois: Allured Publishing Corporation, $4^{\text {th }}$ Edition, $\mathrm{P} 804$

Akinci S, Lösel DM (2012). Plant water-stress response mechanisms. In Rahman IMM, Hasegawa H (Eds.). Water Stress. Croatia: In Tech. pp. 15-42.

Ashengroph M, Nahvi I, Zarkesh-Esfahami H, Momenbeik F (2012). Conversion of isoeugenol to vanillin by Pyschrobacter sp. Strain CSW4. Appl. Biochem. Biotechnol. 166:1-12.

Baghalian K, Abdoshah SH, Khalighi-Sigaroodi F, Paknejad F (2011). Physiological and phytochemical response to drought stress of German chamomile (Matricaria recutita L.). Plant Physiol. Biochem. 49:201-207.

Bahreininejad AB, Razmjoo J, Mirza M (2013). Influence of water stress on morpho-physiological and phytochemical traits in Thymus daenensis. Int. J. Plant Prod. 7:151-166.

Bettaieb I, Zakhama N, Aidi Wannes W, Kchouk ME, Marzouk B (2009). Water deficit effects on Salvia officinalis fatty acids and essential oils composition. Sci. Hortic. 120:271-275.

Blank AF, Carvalho Filho JLS, Santos-Neto AL, Alves PB, ArrigoniBlank MF, Silva-Mann R, Mendonça MC (2004). Caracterização morfológica e agronômica de acessos de manjericão e alfavaca. Hortic. Bras. 22:113-116

Carroll AB, Pallardy SG, Galen C (2001). Drought stress, plant water status, and floral trait expression in fireweed, Epilobium angustifolium (Onagraceae). Am. J. Bot. 88:438-446.

Cominelli E, Galbiati M, Tonelli C (2008). Integration of water stress response Cell expansion and cuticle deposition in Arabidopsis thaliana. Plant Sig. Behav. 8:556-557.

Costa LCB, Pinto JEBP, Bertolucci SKV, Guimarães RM (2010). Qualidade fisiológica de sementes de Ocimum selloi benth. sob condições de luz, temperatura e tempo de armazenamento. Ciênc. Agrotec. 34:675-680.

Daugsch A, Pastore G (2005). Obtenção de vanilina: Oportunidade biotecnológica. Quim. Nova 28:642-645.

De Paula JP, Farago PV, Checchia LEM, Hirose KM, Ribas JLC (2004). Atividade repelente do óleo essencial de Ocimum selloi Benth. (variedade eugenol) contra o Anopheles braziliensis Chagas. Acta Farm. Bonaer. 23:376-388.

Delfine S, Loreto F, Pinelli P, Tognetti R, Alvino A (2005). Isoprenoids content and photosynthetic limitations in rosemary and spearmint plants under water stress. Agric. Ecosyst. Environ. 106:243-252.

Dubey N, Tiwari TNA, Mandin D, Andriamboavonjy H, Chaumont JP (2000). Antifungal properties of Ocimum gratissimum essential oil (ethyl cinnamate chemotype). Fitoterapia 71(5):567-569.

Ferreira D, Sisvar F (2010). Sistema de análises estatísticas para dados balanceados. Versão 5.3. Lavras: UFLA/DEX.

Guerfel M, Baccouri O, Boujnah D, Chaibi W, Zarrouk M (2009). Impacts of water stress on gas exchange, water relations, chlorophyll content and leaf structure in the two main Tunisian olive (Olea europaea L.) cultivars. Sci. Hortic. 119:257-263.

Guha A, Sengupta D, Rasineni GK, Reddy AR (2010). An integrated diagnostic approach to understand drought tolerance in mulberry (Morus indica L.). Flora 205:144-151.

Harb A, Krishnan A, Madana MR, Ambavaram R, Pereira A (2010). Molecular and physiological analysis of drought stress in arabidopsis reveals early responses leading to acclimation in plant growth. Plant Physiol. 154:1254-1271.

Hunt R (1990). Basic growth analysis. London: Unwin Hyman Ltd. P 112.

Jaleel CA, Gopi R, Sankar B, Gomathinayagam M, Panneerselvam R (2008). Differential responses in water use efficiency in two varieties of Catharanthus roseus under drought stress. C. R. Biol. 331(1):4247.

Kaurinovic B, Popovic M, Vlaisavljevic S, Trivic S (2011). Antioxidant capacity of Ocimum basilicum L. and Origanum vulgare L. Extract. 
Molecules 16:7401-7414.

Khalid KHA (2006). Influence of water stress on growth, essential oil, and chemical composition of herbs (Ocimum sp). Int. Agrophys. 20:289-296.

Kriedemann PE, Goodwin I (2003). Regulated deficit irrigation and partial rootzone drying. Canberra: Land \& Water. Australia.

Lambers H, Chapim III FS, Pons TL (2008). Plant Physiological Ecology. Springer: New York (2a Ed.).

Larcher W (2000). Ecofisiologia Vegetal. Rima. São Carlos -São Paulo.

Lemos JA, Passos XS, Fernandes OFL, De Paula JR, Ferri PH, Hasimoto LK, Lemos AA, Silva MRR (2005). Antifungal activity from Ocimum gratissimum L. towards Cryptococcus neoformans. Memórias do Instituto Oswaldo Cruz 100(1):55-68.

Lisar SYS, Motafakkerazad R, Hossain MM, Rahman IMM (2012). Water stress in plants: causes, effects and responses, In: Rahman IMM, Hasegawa H (Eds.). Water Stress. Croatia: InTech. pp. 1-15

Marchese JA, Ferreira JFS, Rehder VLG, Rodrigues O (2010). Water deficit effect on the accumulation of biomass and artemisin in annual wormwood (Artemisia annua L., Asteraceae). Braz. Soc. Plant Physiol. 22:1-9.

Oliveira RA, Reis TV, Duarte LP, Sacramento CK, Oliveira FF (2008). Constituintes químicos voláteis de especiarias ricas em eugenol. Rev. Bras. Farmacogn. 19:771-775.

Osakabe Y, Osakabe K, Shinozaki K, Tran LS (2014). Response of plants to water stress. Front Plant Sci. 5:1-8.

Parry MAJ, Andralojc PJ, Khan S, Peter JL, Keys AJ (2002). Rubisco activity: effects of drought stress. Ann. Bot. 89:833-839.

Pereira CAM, Maia JF (2007). Estudo da atividade antioxidante do extrato e do óleo essencial obtidos das folhas de alfavaca (Ocimum gratissimum L.). Ciênc. Tecnol. Aliment. 27(3):624-632.

Poorter H, Niklas KJ, Reich PB, Oleksyn J, Poot P, Momme L (2012). Biomass allocation to leaves, stems and roots: Meta analyses of interspecific variation and environmental control. New Phytol. 193:3050.

Rehem BC, Bertolde FZ, Almeida AAF (2012). Regulation of gene expression in response to abiotic stress in plants. In: P. Bubulya, (Ed) Cell Metabolism - Cell Homeostasis and Stress Response. Biochem. Genet. Mol. Biol. pp. 15-38.

Reddy AR, Chaitanya KV, Vivekanandan M (2004). Drought-induced responses of photosynthesis and antioxidant metabolism in higher plants. J. Plant Physiol. 16:1189-1202.

Saeidnejad AH, Kafi M, Khazaei HR, Pessarakli M (2013). Effects of drought stress on quantitative and qualitative yield and antioxidative activity of Bunium persicum. Turk. J. Bot. 37:930-939.

Sangwan NS, Farooqi AHA, Shabih F, Sangwan RS ( 2001). Regulation of essential oil production in plants. Plant Growth Regul. 34:3-21.

Scholander PF, Hammel HT, Bradstreet ED, Hemmingsen EA (1965). Sap pressure in vascular plants. Science 148:339-346.

Selmar D, Kleinwächter M (2013). Stress enhances the synthesis of secondary plant products: the impact of stress-related over-reduction on the accumulation of natural products. Plant Cell Physiol. 54:817826.

Shao HB, Chu LY, Jaleel CA, Zhao CX (2008). Water-deficit stressinduced anatomical changes in higher plants. C.R. Biol. 331:215-225.

Simon JE, Reiss-Bubenheim D, Joly RJ, Charles DJ (1992). Water stress-induced alterations in essential oil content and composition of sweet basil. J. Essent. Oil Res. 128:173-175.

Singh-Sangwan NEELAM, Abad Faroogi AH, Singh SR (1994). Effect of drought stress on growth and essential oil metabolism in lemongrasses. New Phytol. 128(1):173-179.

Sneha GMNJ, Sastry PJC (2011). Evaluation of antibacterial activity of Ocimum. Int. J. Pharmacogn. Phytochem. Res. 3:89-92.
Stefan M, Zamfirache MM, Padurariu C, Trută E, Gostin I (2013). The composition and antibacterial activity of essential oils in three Ocimum species growing in Romania. Cent. Eur. J. Biol. 8:600-608.

Valipour M (2013). Increasing irrigation efficiency by management strategies: cutback and surge irrigation. J. Agric. Biol Sci. 8:35-42.

Vani SB, Cheng SF, Chuah CH (2009). Comparative study of volatile compounds from genus Ocimum. Am. J. Appl. Sci. 6:23-528.

Wang S, Liang D, Chao L, Hao Y, Fengwang MA, Shu H (2012). Influence of drought stress on the cellular ultrastructure and antioxidant system in leaves of drought-tolerant and drought-sensitive apple rootstocks. Plant Physiol. Biochem. 51:81-89.

Zhao LQ, Sun Z-H, Zheng P, He JY (2006). Biotransformation of isoeugenol to vanillin by Bacillus fusiformis CGMCC1347 with the addition of resin HD-8. Process Biochem. 41:1673-1676. 